doi:10.29285/actapinteriana.2021.7.13

\title{
First Contacts between Saint Francis and Hungary
}

\author{
Varga Kapisztrán OFM \\ Sapientia Szerzetesi Hittudományi Főiskola, 1052 Budapest, Piarista köz 1. \\ varga.kapisztran@sapientia.hu
}

Varga K. (2021): First Contacts between Saint Francis and Hungary. A ferences rend magyarországi kezdeteinek kérdéséhez: Szent Ferenc, ill. a ferencesek elsö találkozási lehetöségei. Acta Pintériana, 7: 13-20.

\begin{abstract}
A ferences rend és a magyarság találkozásának lelki-szellemi hátterét a IV. Lateráni Zsinat és a „Szentföld eszme” adta. A zsinat megnyitásán III. Ince testi, spirituális és örök átmenetről beszélt, mely a Szentföld felszabadításával, a megtéréssel és a szentségek vételével valósul meg. Szent Ferenc ennek jegyében ,átment” a Szentföldre, megtérése jeleként magára vette a „Taut”, és buzdított a szentségek vételére. A zsinat által meghirdetett V. keresztes hadjárat vezetése II. András magyar királyra várt. A magyarok és a ferencesek találkozására öt alkalom kínálkozott. Az első 1212-ben, amikor Szent Ferenc Szíriába indulva Dalmáciába sodródott, a második a IV. Lateráni Zsinaton. A harmadik a Szentföldön adódhatott, ahol már 1217-től jelen voltak a ferencesek, de ugyanebben az évben érkezett Akkonba a magyar sereg is. Noha a király gyorsan haza utazott, egy kisebb magyar csapat, köztük Tamás egri püspök, ott maradt és részt vett Damietta ostromában is. Minthogy Szent Ferenc járt a Damiettát ostromló keresztesek táborában, Tamás püspök találkozhatott vele, vagy legalábbis hallott róla és testvéreiről. A negyedik érintkezési lehetőséget az Itáliában tanuló magyarok jelentették, a kapcsolat igazi felvétele azonban az volt, hogy a rend 1217-ben elhatározta, Magyarországra is küld testvéreket. Ennek nyomán az első, sikertelen megtelepedési kísérletet 1219-re tesszük, Tamás egri püspökkel azonosítva a testvérek útiköltségét kifizető magyar püspököt. A testvéreket ért inzultusok, melyeket Iordanus említ, valószínüleg az Alföldön történtek. Noha ez a kísérlet sikertelen volt, ekkortájt léphetett be a rendbe az első név szerint ismert magyar, Abraham Hungarus, aki Itáliában tanuló magyar diák lehetett.
\end{abstract}

\section{The common ground: the 4th Lateran Council and the idea of the „Holy Land”}

Hardly anyone would deny today that the 4th Lateran Council had a decisive impact on the development of the Franciscan Order. For scholars of Hungarian history it is equally clear that this council was a most important event in the life of the Kingdom of Hungary and its Church. However, few scholars have yet reflected on the council as a possible first point of contact between the Order and Hungary. We would like to investigate how reasonable such a conclusion would be?

The 12th ecumenical council was summoned for 1 November 1215 by Innocent III as a crowning event of his reign. The significance of this council is raised by the fact that among the 412 bishops and some 800 abbots we find representatives of countries that participated the first time in such an event: Bohemia, Poland, Hungary, Estonia, Latvia (cf. JEDIN 1998, p. 53), including 11 Hungarian prelates (cf. SZÁNTÓ 1983, p. 384). 
The council not only served as an opportunity for Franciscans and the Hungarian bishops to meet personally, but also provided a direction which united the efforts of both groups. The pope chose the "pasqua” or "passover" as the key metaphor for his opening speech (see the text in PL 217,673-680). He explained the ,passover" in a threefold sense. Materially, an army would depart and cross over to liberate Jerusalem. Spiritually, all Christians should complete the passover of leaving their sins behind and entering a life of penance, and this would practically mean a reform of the Church. In the „eternal” sense, Christians should enter the new life by way of the sacraments, which meant a reform of Eucharistic practice. This orientation was consequently put into practice in various ways, even if Innocent III did not live to see the departure of the Crusades (cf. VorREUX 1977).

We know that St. Francis was present at the council where the Legend of Perugia would report the approval and proclamation of the Order by the Pope. ${ }^{1}$ Other sources do not mention this approval. According to the Chronica XXIV Generalium and other - Dominican and Premonstratensian - sources, Francis met here St. Dominic who was equally working on a papal approval of his group. ${ }^{2}$ The speech of the pope deeply touched Francis and he fully accepted this orientation. He accomplished the "transitus" to the Holy Land in his own way. It is equally known that his use of the letter Tau and his emphasis of the Eucharist were clearly promoted by the pope's speech at the council.

The first „Passover”, according to the flesh, as Innocent III announced it, meant the departure of an army of Crusaders to liberate Jerusalem. Hungary joins the council program of the Pope by taking part in the military campaign under the leadership of King Andrew. Thus, the idea of the Holy Land may be considered the first spiritual link between Franciscans and Hungary. Let us not forget that not only a huge army, but a significant group of pilgrims also departed in 1217 from Hungary to Palestine (cf. BOZSÓKY 1995, p. 126). Two aspects are of particular importance for us in the fifth crusade.

1. The king of Hungary left from the Adriatic coast to arrive in Akkon during the autumn of 1217. After unlucky military efforts we find him again in Akkon on 1 January 1218.

2. Several of the prelates of Hungary accompanied the king to the Holy Land: Peter, bishop of Györ, Thomas, bishop of Eger, Robert, bishop of Veszprém, provost Ugrin, royal chancellor, and Uriah, abbot of the Benedictines of Pannonhalma. We note that the king himself asked the Pope for permission for bishops Peter and Thomas to be absent from the council while preparing the crusades, whereas bishop Robert and abbot Uriah were present at the council (cf. SUGÁR 1984, p. 63). Thomas of Eger certainly did not return together with the king but remained in the Holy Land with some troops and took part in the siege of Damiette. According to Bozsóky, Robert of Veszprém, Peter of Győr and Simon, bishop of Várad later returned to Palestine and the latter two fell at Damiette (cf. BozSÓKY 1995, pp. 136-137). ${ }^{3}$

The Hungarian troops under the command of Simon joined the Crusaders at Damiette in May 1218. As it is known, three battles were fought during the long siege, with a crushing defeat on 29 August. Papal legate Pelagius refused the proposal of the Sultan for a peace, and the fortress was taken on 5 November 1219 at great costs, only to be given up after a short time (cf. BOZSÓKY 1995, pp. 100-103). ${ }^{4}$

\footnotetext{
„Ipse approbavit et concessit sibi et postea in concilio omnibus annuntiavit” (Legenda Perusina 67,8).

„Anno Domini MCCXV tempore Concilii Generalis beatus Franciscus Romam adiit et sanctum Dominicum, qui ibi tunc erat pro sui Ordinis approbatione, repperit, quem Dei ostensa visio sibi favorabilem fecit" (Chronica XXIV Generalium in AF III, 9; see also CLARENUS 1912, pp. 6, 16, 101).

3 Chronicles also speak about two Hungarian bishops who died at Damiette (see the Annales Reinhardsbrunnenses in Gombos 1937a, p. 192; and also the Chronica S. Petri Erfordensis moderna in GomBos 1937a, p. 471).

4 Proposing 19 November as the date of conquering of Damiette by the Crusaders.
} 
It is important that Thomas, bishop of Eger only left on 14 September 1219 for Hungary, ${ }^{5}$ which means he arrived early 1220 in his country.

In the meantime, the first Franciscan friars appeared in the Near East due to the chapter decision in 1217. The Order was organized into provinces, and friars were sent also to „overseas”, i.e. to the Holy Land, with Elia of Cortona as the first minister. ${ }^{6}$ In 1219 Saint Francis himself went to the Holy Land. ${ }^{7}$ He boarded the ship at Ancona on 24 June, arrived in Akkon and reached Damiette in late August. We have the story of prophesying the defeat of 29 August. As it fulfilled, Crusaders were inclined to do penance. ${ }^{8}$ This may have led many of them to join Saint Francis. ${ }^{9}$ The encounter between Francis and Sultan Melek el-Kamil at this time can be considered a well-established fact. After the occupation of Damiette ${ }^{10}$ however, he left the troops to visit the shrines. News from Italy made him leave Palestine in December 1219 or later (cf. BALANYI 1927, p. 318). ${ }^{11}$

\section{Possibilities of a first contact}

This account presents us an important spiritual issue that occupied both the Kingdom of Hungary and the Franciscan Order at that time. It is to be noted that Hungary was an influential region of the Christian world at this time so the participation of Hungary in these „European” issues was obvious for the contemporaries, a circumstance sometimes forgotten in our days.

In chronological order, the first opportunity for Hungarians to meet Saint Francis might have been, in theory, in 1212 when Francis is reported by Celano to have reached the Dalmatian coasts in a storm (cf. 1Cel 55 in Fontes Franciscani 1995, p. 329). Karácsonyi and after him Balanyi believe that Francis touched land at Zara where he founded a friary (cf. KARÁCSONYI 1923, pp. 6-7; BALANYI 1927, pp. 273-274). I prefer not to pronounce any judgment on this, as recent Croatian historical works only mention this in passing (cf. MIRKOVIĆ \& HOŠKO 2000, p. 12; HOŠKO 2000, p. 18). ${ }^{12}$ It goes against the hypothesis of Francis having founded a friary at this time that the friars sent to Hungary in 1217 or 1219 would have had more success in their mission had they found in Zara a convent existing already for years. It would certainly have served as a base in many respects, but there is no later reference (cf. Chronica fratris Iordani a Iano 6.c. in AF I, p. 3) to this.

The second opportunity was offered by the 4th Lateran Council, but Saint Francis may not have been so strongly in the focus of attention that Hungarian prelates should have been looking for a chance to meet him.

The third opportunity, certainly much more probable than the first two, is to be regarded in the issue of the Holy Land. No matter that the first Franciscans went to Syria in 1217, Saint Francis went to Akkon and Damiette. The Hungarian bishops who fell during the siege were still alive and so was

5 We read in Codagnellus in Gombos 1937b, p. 1297: „In exaltatione sanctae crucis [a. 1219. Sept. 14] Romanorum princeps et episcopus Ungariae [Thomas Agriensis] patriam rediderunt."

6 „Frater autem Helias minister provincialis est institutus ultra mare a beato Francisco”" (Chronica fratris Iordani a Iano in AF I, p. 4); about Franciscan beginnings see also PANDŽIĆ 1974, pp. 7-8.

7 We took the dates for the journey of Francis in the Holy Land from the detailed account in BALANYI 1927, pp. 305-318; see also ORTROY 1912, pp. 451-462.

8 „Urgebat ergo sanctum de ipsis compassio, nec minus eos poenitudo de facto” (2Cel 30,13 in Fontes Franciscani 1995, p. 471).

9 We know the account of Jacques de Vitry, Epist. IV. listing the persons who left his train: prior Rainerius, cleric Colin, magister Michael and Vicar Matheus, adding: ,cantorem et Henricum et alios quosdam vix retineo” (HuYGENS 1960, pp. 131-133).

10 Bozsóky gives us 19 November, while Balanyi 5 November (cf. BALANYI 1927, p. 314).

11 Reviews the opinions of scholars about the date of return.

12 Pandžić says that many Dalmatian convents date their foundation from this visit, but we have no written proof of the existence of Franciscan convents from this period (cf. PANDŽIĆ 1974, p. 109). 
Thomas of Eger. We can reasonably argue that they were informed about the visit of Francis and the stories about his Order. If Jacques de Vitry writes about him in such a way as in the Historia Orientalis, then it is hardly possible that Francis would not have been a topic of conversation (cf. HINNEBUSCH 1972, pp. 158-163; BEER 1983). The fact that people joined his Order even in the Holy Land must have been an extraordinary circumstance. We can presume that Thomas, bishop of Eger got acquainted with the friars at Damiette, and he may well have been the Hungarian bishop mentioned by Jordanus who in 1219 helped the friars cross the Adria (cf. CODAGNELLUS in GOMBOS 1937b, p. 1297). It is interesting that 18th century historians often link the foundation of the first friary in Hungary - whether in Buda, Zagreb or Eger - with the return of Andrew II from Syria or with the return of Francis from the Holy Land (cf. ESZTERLE 1925, pp. 3-12).

The fourth opportunity for Hungarians to meet Francis or his movement was offered by Italian universities where several Hungarians were studying at that time. The speech of Francis in 1222 in Bologna and its effects were written down by archdeacon Thomas of Spalato (cf. Spalatensis in Monumenta Germaniae Historica 1905-1913, p. 580; BOEHMER 1961, p. 106; LEMMENS 1926, p. 10). As the history of Dominicans in Hungary witnesses, Hungarian students of Italian universities played an important role in getting acquainted with the Order and spreading it in Hungary.

The fifth and most certain opportunity is beyond doubt the decision of the Order to send friars to Hungary, as taken by the general chapter of 1217 or 1219 .

\section{The first, unsuccessful attempt to settle in Hungary}

Any discussion about the first attempt of the Order to settle in Hungary has to face the uncertainty about the date of this chapter decision. Debate on this has been going on for about a century now. Surely there was a decision in 1217 to send friars to countries outside Italy and overseas. It is still debated whether these countries included all that are indicated in the sources (Spain, France, Germany and Hungary) or the sending out was carried out in two waves.

Even the sources diverge in describing this event. The chronicler of the settlement in Germany, Jordanus a Giano, writes in ch. 3:

„Anno vero Domini 1219 et anno conversionis eius decimo frater Franciscus in capitulo habito apud sanctam Mariam de Portiuncula misit fratres in Franciam, in Theutoniam, in Hungariam, in Hispaniam, et ad alias provincias Italiae, ad quas fratres non pervenerant."

(Chronica fratris Iordani a Iano in AF I, p. 2)

However, year 10 of the conversion of Francis cannot be 1219, but only 1217. Even if the AF edition mentions a theory to read ",tertio" instead of ,frater", Jordanus writes correctly in ch. 10 that Francis went to the Holy Land in year 13 of his conversion, that is in 1219. All further authors carry on this uncertainty of Jordanus.

Our position is that the chapter decision is to be dated for 1219. We have found it helpful what Pietro Messa suggested (cf. MESSA 2001, pp. 4-7), emphasizing the remark of Jordanus that sending friars outside the Italian peninsula at that time was equal to being ready for martyrdom. ${ }^{13} \mathrm{We}$ know that at the chapter of 1221 friars were not ordered to join the mission to Germany but had to volunteer. The chronicle of Jordanus can be taken as a good example of how missions were organized in those years.

Our basic argument for dating the first attempt at 1219 is an implicit proposition made by Jordanus and never looked into by scholars until know. Jordanus says that it was a Hungarian bishop who paid

13 „Ex quo facto Theutonia a fratribus tam crudelis est reputata, ut ad ipsam nisi desiderio martyrii inspirati redire non auderent" (Chronica fratris Iordani a Iano in AF I, p. 3; see also chapters 17-18 in AF I, pp. 6-8). 
the voyage of the friars to Hungary. Were there any Hungarian bishops returning in 1217 via Ancona? Hardly in 1217, for they were rather leaving for the Holy Land than returning. However, we find Thomas, bishop of Eger, returning on 14 September 1219 from the Holy Land. We do not know the exact route he took, and this surely weakens our argument. But if we go with this, it may shed light on the date of the first mission and on the identity of the bishop mentioned by Jordanus.

The description of the first unsuccessful mission journey to Hungary is found in ch. 6 of the chronicle of Jordanus. Later sources seem to borrow his story, with modifications, but leaving the essence unchanged. This description is the longest among those about missions to European countries, probably because of its adventurous character, as we can gather from the text of the Chronica anonyma. ${ }^{14}$ Another reason for this special interest of Jordanus can be that members of the group included friars he closely knew. In the same chapter he mentions that the weird story had been told to him by someone who had lost his pants fifteen times. In ch. 18 he tells us that he turned for advice to a friar who had seen many tribulations, having lost his pants six times in Hungary. Here is how Jordanus recalls the event:

\begin{abstract}
„Fratres vero in Hungariam missi per quendam episcopum Hungariae per mare in Hungariam sunt conducti, et cum derisi per campos encederent, pastores ipsos canibus inpetierunt et aversa cuspide sub silentio incessanter eos lanceis percusserunt. Et cum inter se fratres conquirerent, quare sic mactarentur, dixit unus: „Forte quia tunicas nostras superiores habere volunt«. Quas cum dedissent, nec sic a verberibus destiterunt. Et adiecit: "Forte etiam et nostras tunicas inferiores habere volunt". Quas cum dedissent, nec sic percutere destiterunt. Et dixit: "Forte et bracchas nostras habere volunt». Quas cum dedissent, a verberibus destiterunt, et nudos abire permiserunt. Et mihi retulit unus ex eisdem fratribus, quod XV vicibus ipse sic bracas amiserat. Et cum, pudore et verecundia victus, plus de braccis quam de aliis vestibus doleret, ipsas braccas luto boum et aliis immunditiis polluit, et sic ipsi pastores super eis nauseam habentes ipsi braccas retinere concesserunt. Et hi aliis pluribus contumeliis affecti in Italiam sunt reversi."
\end{abstract}

(Chronica fratris Iordani a Iano in AF I, p. 3$)^{15}$

The general chapter of 1219 started on 26 May. Even if we accept the date of 24 June 1219 for St. Francis to board the ship in Ancona to the Holy Land (cf. BALANYI 1927, pp. 303-305), we can reasonably presume several months before friars actually left for the mission. An example would be the mission to Germany: the chapter started on 30 May, but friars only arrived in Trento on 29 September (cf. Chronica fratris Iordani a Iano in AF I, p. 8). A certain preparation may have been possible, but this was not typical for friars at that time. It is unknown whether they tried another route or went directly to Ancona, to use the then usual route between Hungary and Rome via Dalmatia.

The real difficulty must have been paying the fare in Ancona, and they were a fairly big group at that. Jordanus mentions 25 friars leaving for Germany in 1221, later groups of about 10 to various regions: 10 friars to Saxony in 1223, 7 to Thuringia in 1224 (cf. Chronica fratris Iordani a Iano ch. 19, 34 and 38, in AF I, pp. 8, 12). We can think of this size for the group leaving for Hungary. They could hardly have expected any ship to take them without paying. We know the story of St. Francis from 1212 when he was refused by the Ancona sailors as he was trying to board a ship (1Cel 55). The only thing the group could do was to wait until they find someone to pay for the voyage. This could have been

14 „Diversum tamen accidit iis, quibus Hungaria sorte contigit, quod visum fuit hic commemorare” (Chronica anonyma Fratrum Minorum Germaniae in AF I, p. 280).

15 The Chronica anonyma Fratrum Minorum Germaniae of the Sant'Isidoro convent in Rome borrows several stories from Jordanus, such as this one (cf. Chronica anonyma in AF I, p. 280). Iohannes de Komorowo in his Memorialia ordinis fratrum Minorum, maxime rectorum ipsius ordinis et contingencium in ordine dates the event at 1216 with reference to Jordanus (cf. GoMBOS 1937b, pp. 1299-1300). Wadding gives us another version of the story in WADDING 1931, a. 1219, n. 42. 
made easier if they could only present the papal letter Cum dilecti filii, issued on 11 June 1219, but we do not know if they carried this letter or not. ${ }^{16}$ They had to find someone who knew them and had enough money. A Hungarian bishop to meet both requirements could be Thomas of Eger who started his return trip on 14 September 1219 in Damietta. He had an opportunity to get acquainted with the Order in the Holy Land, may even have met St. Francis during the siege of Damietta, and certainly had the money to help the friars. thus we can reasonably argue that Thomas was the Hungarian bishop who helped the friars to cross the Adriatic Sea to Zara.

We do not find any indication of a season in any description. It only means that they did not meet with extreme cold. Thus we can think of autumn 1219 or even spring 1220.

No exact location can be given for the insults described in the text. There is a scholarly tradition speaking about pastors in the Dinari mountains (cf. KARÁCSONYI 1923, p. 8; BALANYI 1940, p. 8). This is contradicted by the mention of ,per campos" in Jordanus, and further by the words of Wadding and the Chronica Anonyma: ,, nam cum per campos hinc inde [Wadding: divisi] errarent, pecorum custodes - brutum et ferox genus - [...] eos verberantes, gravissime excrutiarunt" (WADDING 1931, a. 1219, n. 42.). We cannot propose any exact location on the basis of this text, but we can certainly say that the events did not happen in the mountains but on a plain. Another argument is the expression pecorum custodes which also suggests a plain. This would mean that the friars reached further inland than Dalmatia, but raises the question why they did not visit any town on their way where they could have settled? Were they determined to go directly to the capital or were they looking for a town with a bishop? The texts do not offer any more clues.

We have argued to date of the first attempt to settle in Hungary for 1219. Even if the story given by Jordanus offers only a few clues, it leaves no room for assuming a settlement before 1219 .

\section{The first known Hungarian Franciscan: Abraham Hungarus}

There are several things we can learn about Abraham Hungarus, the first known Hungarian friar, on the basis of the chronicle of Jordanus a Giano. Perhaps not as many as we would like, but certainly more than has been analysed until now (cf. ESZTERLE 1925, p. 13; KARÁCSONYI 1923, p. 6). ${ }^{17}$

As we know it from ch. 17 of Jordanus, Abraham was present at the Chapter of Mats of 1221. Since this chapter was the last in which all the friars were participants, and the novitiate year was introduced on 22 September 1220 (Cum secundum consilium), Abraham must have joined the Order before this date. Abraham was thus witness of this important chapter which - under the presidence of Fr. Elias worked on the rule that was to become the Regula non Bullata and chose friars for the missions.

Abraham volunteered for the mission, which means either that he had courage or that he knew the language of the mission country (cf. Chronica fratris Iordani a Iano ch. 7, in AF I, pp. 6-7). He became the companion of several well-known friars like Cesarius of Speyer, Thomas of Celano, John of Pian Carpino and the chronicler Jordanus a Giano. He is mentioned among the 12 clerics (cf. Chronica fratris Iordani a Iano ch. 19, in AF I, p. 8), but was ordained only in 1222 with two others (cf. Chronica fratris Iordani a Iano ch. 28, in AF I, p. 11). Presumably he was a young man at this time, but already finished the studies necessary for ordination. He could well be one of the many Hungarian students studying at Italian universities at this time, which gave him a chance to contact the friars.

16 We do not know if the friars brought with themselves the papal letter of privilige „XXX” of 11 July 1219, but if they did, that must have been of great help (cf. WADDING 1931, a. 1219, n. 28).

17 The most we find in the study of Balanyi on the formation of the Hungarian Franciscan province (cf. BALANYI in id. 1930, p. 135). 
We also know that after the provincial chapter held in Augsburg on 16 October 1221 Cesarius of Speyer sent him to Salzburg together with fr. Jordanus and fr. Constantinus (cf. Chronica fratris Iordani a Iano ch. 23-24, in AF I, p. 9). ${ }^{18}$ This is the last mention of his name in the chronicle of Jordanus. He is thought to have participated in the settlement of the Order in Hungary, but there are no indications to prove this.

Translated from Hungarian by Jakab Várnai OFM

\section{Irodalom - References}

Analecta Franciscana (1885-1941). t. I-X., Collegium S. Bonaventurae, Ad Claras Aquas, Quaracchi, Florentiam. [AF]

Annales Reinhardsbrunnenses. In: A. GomBos (ed.) (1937a): Catalogus fontium historiae Hungaricae (A-C). t. 1., Szent István Akadémia, Budapest, pp. 187-193.

Archivum Franciscanum Historicum. Collegium S. Bonaventurae, Quaracchi (1908-1970); Grottaferrata (1971 ss.). [AFH]

BALANYI, Gy. (1930): A magyar ferences provincia kialakulása. In: id.: Anima Franciscana (1930). Ferences Közlöny, Budapest, pp. 132-150.

BALANYI, Gy. (1940): A ferences mozgalom begyökerezése magyar földön. Székfoglaló értekezés, Értekezések a Történeti Tudományok Köréböl 25/10., Magyar Tudományos Akadémia, Budapest.

BALANYI, Gy. (1927): Assisi Szent Ferenc. Szent István Társulat, Budapest.

BEER, F. de (1983): ,,We saw Brother Francis”. Franciscan Herald Press, Chicago.

BOEHMER, H. (ed.) (1961): Analekten zur Geschichte des Franziskus von Assisi. J. C. Mohr (Paul Siebeck), Tübingen.

BOZSÓKY, P. G. (1995): Keresztes hadjáratok. Agapé, Szeged.

Chronica anonyma Fratrum Minorum Germaniae (1885). In: Analecta Franciscana (1885). t. I., Collegium S. Bonaventurae, Quaracchi, Florentiam, pp. 277-300. [AF I]

Chronica fratris Iordani a Iano. In: Analecta Franciscana (1885). t. I., Collegium S. Bonaventurae, Quaracchi, Florentiam, pp. 1-19. [AF I]

Chronica S. Petri Erfordensis moderna. In: A. GoMBOS (ed.) (1937a): Catalogus fontium historiae Hungaricae $(A-C)$. t. 1., Szent István Akadémia, Budapest, pp. 471-474.

Chronica XXIV Generalium. In: Analecta Franciscana (1887). t. III., Collegium S. Bonaventurae, Quaracchi, Florentiam. [AF III]

Clarenus, A. (1912): Expositio Regulae Fratrum Minorum. Collegium S. Bonaventurae, Quaracchi, Florentiam. (ed. L. Oliger)

Codagnellus, I. (Caputagni): Gesta obsidionis Damietae a. 1218-1219. In: A. GomBos (ed.) (1937b): Catalogus fontium historiae Hungaricae (D-N). t. 2., Szent István Akadémia, Budapest, p. 1297.

ESZTERLE, J. (1925): Mikor jöttek a ferencesek Magyarországba és hol épült első kolostoruk? Buzárovits Gusztáv Könyvnyomdája, Esztergom.

Gombos, A. (ed.) (1937a): Catalogus fontium historiae Hungaricae $(A-C)$. t. 1., Szent István Akadémia, Budapest.

18 All this is born out also by the Chronica anonyma Fratrum Minorum Germaniae in AF I, pp. 281-283. 
Gombos, A. (ed.) (1937b): Catalogus fontium historiae Hungaricae (D-N). t. 2., Szent István Akadémia, Budapest.

HINNEBUSCH, J. F. (ed.) (1972): The Historia Occidentalis of Jacques de Vitry. Spicilegium Friburgense 17., University Press, Fribourg.

HoŠKO, F. E. (2000): Franjevci u kontinentalnoj Hrvatskoj kroz stoljeća. Analecta Croatica Christiana 32., Kršćanska sadašnjost, Zagreb.

HUYGENS, R. B. S. (ed.) (1960): Lettres de Jacques de Vitry (1160/1170-1240). Brill, Leiden.

In Concilio Generali Lateranensi habitus (Sermo VI.). Innocentii III Papae Sermones de Diversis. In: PL 217,673-680.

JEDIN, H. (1998): A zsinatok története. Ecclesia, Budapest.

KARÁCSONYI, J. (1923): Szt. Ferenc rendjének története Magyarországon 1711-ig. 1. köt., Magyar Tudományos Akadémia, Budapest.

KARÁCSONYI, J. (1924): Szt. Ferenc rendjének története Magyarországon 1711-ig. 2. köt., Magyar Tudományos Akadémia, Budapest.

Legenda Perusina (1195). In: E. MENESTÒ; S. BRUFANI; E. PAOLI; L. PELLEGRINI \& G. BOCCALI (a cura di) (1995): Fontes Franciscani. Ed. Porziuncola, Assisi, pp. 1471-1687. [Legenda Perusina]

LEMMENS, L. (1926): Testimonia minora saeculi XIII. de S. Francisco Assisiensi. Collegium S. Bonaventurae, Quaracchi, Firenze.

Menestò, E; S. BRUfani; E. PAOLI; L. Pellegrini \& G. BoCCALI (a cura di) (1995): Fontes Franciscani. Ed. Porziuncola, Assisi. [Fontes Franciscani]

MessA, P. (2001): Un francescano alla corte dei Mongoli: Fra Giovanni da Pian del Carpine. In: P. MesSA (a cura di): I Francescani e la Cina 800 anni di storia. Ed. Porziuncola, Assisi, pp. 1-48.

MiRKOvić, M. \& F. E. HoŠKO (uredn.) (2000): Mir i Dobro, Umjetničko i kulturno naslijeđe Hrvatske Franjevačke Privincije Sv. Ćirila i Metoda, O proslavi stote obljetnice utemeljena 12. siječnja - 23. travnja 2000. Galerija Klovićevi dvori, Zagreb.

OrTROY, F. van (1912): Saint François et son Voyage en Orient. Annalecta Bollandiana, 31: 451-462. doi:10.1484/j.abol.4.00018

PANDŽIĆ, B. (1974): Historia Missionum OFM. vol. 4., Secretariatus Missionum, Roma.

SPALATENSIS, T.: Historia Salonitanorum pontificum, atque Spalatensium. In: Monumenta Germaniae Historica (1905-1913). Inde ab anno Christi Quingentesimo usque ad annum Millesimum et Quingentesimum. t. 29., Impensis Bibliopolii Aulici Hahniani, Hannoverae - Lipsiae.

SUGÁR, I. (1984): Az egri püspökök története. Szent István Társulat, Budapest.

SZÁNTÓ, K. (1983): A katolikus egyház története. 1. köt., Ecclesia, Budapest.

SZÁNTÓ, K. (1985): A katolikus egyház története. 2. köt., Ecclesia, Budapest.

SZÁNTÓ, K. (1987): A katolikus egyház története. 3. köt., Ecclesia, Budapest.

TOMMASO, da Celano: Vita prima sancti Francisci. In: E. MENESTÒ; S. BRUFANI; E. PAOLI; L. PELLEGRINI \& G. BocCALI (a cura di) (1995): Fontes Franciscani. Ed. Porziuncola, Assisi, pp. 273-424. [1Cel]

TOMMASO, da Celano: Vita secunda sancti Francisci. In: E. MENESTÒ; S. BRUFANI; E. PAOLI; L. PELLEGRINI \& G. BoCCALI (a cura di) (1995): Fontes Franciscani. Ed. Porziuncola, Assisi, pp. 443-639. [2Cel]

VORREUX, D. (1977): Un Symbole Franciscain. Le Tau. Éd. Franciscaines, Paris.

WADDING, L. (1931): Annales Minorum (1208-1220). t. 1., Collegium S. Bonaventurae, Quaracchi, Florentiam. 